\title{
INSECTICIDAL EFFECT OF FRUIT EXTRACTS FROM Xylopia aethiopica AND Dennettia tripetala (ANNONACEAE) AGAINST Sitophilus oryzae (COLEOPTERA: CURCULIONIDAE)
}

\author{
Donald A. Ukeh ${ }^{1 *}$, Ene E. Oku², Idorenyin A. Udo ${ }^{1}$, Abo I. $\mathrm{Nta}^{2}$, and Jude A. Ukeh ${ }^{3}$
}

The insecticidal and repellent activities of fruit extracts of Xylopia aethiopica (Dunal) A. Rich. and Dennettia tripetala (Baker f.) G.E. Schatz belonging to the family Annonaceae was studied against Sitophilus oryzae (L.), an economic, primary post-harvest pest of rice, and other cereal products. Infested rice grains (100 g) treated with 1, 2, 3, 4, and 5\% (w/w) powders of both plants were evaluated for toxicity against $S$. oryzae every $24 \mathrm{~h}$ for 3 d, and during $\mathrm{F}_{1}$ progeny emergence. The essential oils of both plants were also applied at $0.5,1,1.5$ and $2 \mathrm{mg} \mathrm{cm}^{-2}$ filter paper in Petri dishes for toxicity bioassays at $24 \mathrm{~h}$ exposure. Repellence bioassay with $10 \mu \mathrm{L}$ solution of essential oils on filter paper was performed in a Y-Tube airflow olfactometer. Results indicate that powders of both plants significantly $(P<0.001)$ caused adult weevil mortality and a reduction in $\mathrm{F}_{1}$ progeny emergence than the control. Essential oils were also significantly $(\mathrm{P}<0.001)$ adulticidal to $S$. oryzae after $24 \mathrm{~h}$ with the highest dose $\left(2 \mathrm{mg} \mathrm{cm}^{-2}\right)$ producing $100 \%$ mortality respectively. Similarly, both male and female weevils significantly avoided the test arm compared to the control arm in the Y-Tube olfactometer repellence tests. These results suggest that $X$. aethiopica and D. tripetala natural extracts have potential for use as part of integrated pest management of stored product protection against S. oryzae.

Key words: Essential oils, powders, repellence, toxicity, Y-Tube olfactometer.

\begin{abstract}
A mong the cereals, rice, Oryza sativa L. (Poaceae), is the most important staple food supplying energy and protein requirements for nearly half of the world's population. The harvested crop is often stored to provide future food, income, feed, raw material for industries and planting. However, during storage, losses of cereals such as rice grains can range from 10 to $20 \%$ of overall production, and a primary factor in these losses is the depredations of stored-product insect pests (Rajendran and Muralidharan, 2001; Phillips and Throne, 2010). The rice weevil, Sitophilus oryzae (L.) (Coleoptera: Curculionidae), is an important pest of stored cereals and processed cereal products in tropical and warm temperate regions of the world (Dal Bello et al., 2001; Rees, 2004).

But concerns regarding the continuous use of conventional insecticides, including difficulties in registration of those insecticides in some countries, development of resistance by pest organisms, persistence in the environment, elimination of beneficial organisms, mammalian toxicity, residues on food (Daglish, 2004; Sousa et al., 2009), higher cost of crop production
\end{abstract}

${ }^{1}$ University of Calabar, Department of Crop Science, PMB 1115, Calabar, Nigeria. "Corresponding author (donald.ukeh@yahoo.co.uk). ${ }^{2}$ University of Calabar, Department of Zoology and Environmental Biology, PMB 1115, Calabar, Nigeria.

${ }^{3}$ University of Nigeria, Department of Botany, Nsukka, Nigeria. Received: 3 October 2011.

Accepted: 25 May 2012. and technical difficulties at times of application, have led researchers to the evaluation of new reduced-risk insecticides to control stored-product pests. Low human and eco-toxicity have been the subject of much attention for alternative control measures of stored-product pests protection.

Different spice and herbal plant products in the form essential oils (EO), powders, pellets, extracts or distillates could be harnessed as potential toxicants, deterrents, antifeedants, repellents, and fumigants for exclusion of stored-product pests from grain, and have been used, but low toxicity has obtained much attention for alternative control measures of stored-product pests. Diverse essential oils (EOs) and other plant products have been used.

The African pepper or spice tree, Xylopia aethiopica (Dunal) A. Rich. (Annonaceae), is an important, evergreen, medicinal plant widely distributed in West Africa, and concoctions prepared from its morphological parts are used in traditional medicine for the treatment of skin infections, candidiasis, cough, fever, dysentery and stomach ache (Okigbo et al., 2005). Extracts from $X$. aethiopica have been reported to exhibit anti-bacterial and antifungal (Okigbo et al., 2005), mosquito repellent (Adewoyin et al., 2006) and termite antifeedant (Lajide et al., 1995) activities. Pepper fruit, Dennettia tripetala (G.) (Baker f.) G.E. Schatz (Annonaceae), is a woody forest and spicy plant, cultivated in Southern states 
of Nigeria, where the leaves and fruits are used in combination with other herbs for the treatment of cough, infantile convulsion, and worm infestation (Ejechi and Akpomedaye, 2005). Dennettia tripetala extracts have also been reported to exhibit insecticidal (Egwunyenga et al., 1998), and antifungal (Nwachukwu and Osuji, 2008), properties.

The objectives of this study were to investigate the insecticidal and repellent properties of X. aethiopica and $D$. tripetala fruit powders and essential oils against $S$. oryzae of stored rice.

\section{MATERIALS AND METHODS}

\section{Insects and plant materials}

The study was conducted between June and December 2010 in the laboratory of the Department of Crop Science, University of Calabar, Nigeria. Sitophilus oryzae used in this study was obtained from laboratory cultures maintained on untreated rice at $25 \pm 1^{\circ} \mathrm{C}, 65-70 \%$ relative humidity. Three day old male and female adult weevils were used for the experiments.

Untreated rice was purchased from Obudu Local Government Foodstuff market, and matured ripe fruits of $X$. aethiopica and D. tripetala were bought from Marian Foodstuff Market Calabar. The identity of plant materials was confirmed in the Department of Crop Science, University of Calabar. The fruits were rinsed with tap water and oven dried at $30{ }^{\circ} \mathrm{C}$ for $3 \mathrm{~d}$. Dried fruits were milled into powder with a mechanical blender, weighed into several doses and sealed in transparent plastic containers until needed.

\section{Extraction of essential oils}

Powders of $X$. aethiopica and D. tripetala (150 g) were separately extracted with $250 \mathrm{~mL}$ distilled hexane for 24 $\mathrm{h}$ at room temperature. The extract was filtered through filter paper and the residue re-extracted for another $24 \mathrm{~h}$ before filtration. Hexane was evaporated under vacuum using a rotary evaporator at room temperature to obtain the essential oils (EO), which were sealed in glass vial and stored in the refrigerator until needed.

\section{Insecticide effect of plant powders}

Rice seeds (100 g) were treated with 1, 2, 3, 4, and 5\% (w/w) X. aethiopica or D. tripetala powders in separate transparent plastic containers, with screwed lids to avoid escapes with a drilled hole covered with nylon mesh for ventilation, while the controls received no plant powders. Twenty pairs of 3-d old $S$. oryzae adults were set into each container-treatment for mating and oviposition for $6 \mathrm{~d}$. The plastic containers had their covers drilled with holes to facilitate air circulation. They were then covered with nylon mesh and their perforated lids screwed in place to facilitate confinement of the weevils. Each treatment was replicated six times and laid out in a completely randomized design on the laboratory bench. A mortality count was carried daily for $3 \mathrm{~d}$ after treatment (DAT) by sieving out the contents into a clean white tray and counting the number of dead insects. Each time a count was done; dead individuals were discarded while live ones were returned to their respective treatments. Weevils were considered dead if they did not react or move when lightly probed with a dissecting needle. After $6 \mathrm{~d}$ all live and dead weevils were removed and discarded, and the seeds kept aside to wait for $F_{1}$ progeny emergence. The emerged $F_{1}$ progeny was removed and counted to give a measure of daily productivity. The experiment was ended after 3-mo when no more adult weevils emerged from any treatment.

\section{Adulticidal activity of essential oils}

Bioassay on the toxicity of $X$. aethiopica or D. tripetala EO against adult $S$. oryzae was similar to the method described in Bekele and Hassanali (2001) in Pyrex glass Petri dishes (10 cm diameter). Different doses of each EO were dissolved in $1 \mathrm{~mL}$ distilled hexane and delivered to the Petri dishes pre-lined with Whatman $\mathrm{N}^{\circ} 1$ filter paper. Essential oil solutions were applied at doses of $0.5,1.0,1.5$, and $2.0 \mathrm{mg} \mathrm{cm}^{-2}$, while the control received only hexane. Thirty seconds was allowed for the solvent to evaporate, and 10 pairs of $S$. oryzae adults were introduced into each Petri dish. The Petri dishes were sealed and maintained in the laboratory for $24 \mathrm{~h}$ at ambient temperature and relative humidity. All treatments were replicated six times, and a count of dead weevils was made after $24 \mathrm{~h}$.

\section{Repellence of essential oils}

Solutions of the EO in distilled hexane $\left(1 \mathrm{mg} \mathrm{mL}^{-1}\right)$ were prepared for the repellence bioassay. Bioassays were conducted using a glass Y-tube olfactometer $(2 \mathrm{~cm}$ internal diameter [id], $16 \mathrm{~cm}$ stem length, $14 \mathrm{~cm}$ arms length $)$ in a black cage set up $(60 \times 60 \times 80 \mathrm{~cm})$ consisting of a wooden frame covered with black cardboard paper to avoid external visual cues. Uniform illumination was provided by a fluorescent light tubes positioned about 30 $\mathrm{cm}$ above the Y-tube junction. A pump provided an air stream that was passed through an activated charcoal filter, and then split through two flow meters at $100 \mathrm{~mL}$ $\mathrm{min}^{-1}$ to each of the olfactometer arms. Each airstream then passed through a glass side arm containing $10 \mu \mathrm{L}$ test stimuli ( $X$. aethiopica or D. tripetala EO) or $10 \mu \mathrm{L}$ solution of solvent (distilled hexane) or a piece of filter paper. Adult $S$. oryzae were kept singly and starved for 24 $\mathrm{h}$ before used for the experiments. Ten weevils were used for each bioassay, and each experiment was replicated 12 times. After each replicate, the olfactometer was rotated $180^{\circ}$ to avoid directional effects. During the bioassay, each weevil was introduced individually into the base of the Y-tube and the numbers of weevils entering each arm were recorded. An insect was deemed to have made a final choice if it spent $15 \mathrm{~s}$ in motion beyond the choice line 
without crossing back out again or if it entered an arm but did not return back within $30 \mathrm{~s}$ to enter the opposite arm. An insect was tested only once, while odor sources and olfactometers changed after every replication. All bioassays were conducted between 09:00 and 12:00 h, but with treatments alternated, to avoid any effect of the time of the day on the response.

\section{Statistical analysis}

Data obtained from contact toxicity tests of plant powders and EO were subjected to ANOVA followed by comparison of means by Tukey's 95\% simultaneous confidence intervals. The Y-tube olfactometer data were analyzed using a paired t-test after ensuring that data were normally distributed (GenStat Version 13 statistical software, VSN International Ltd., Hemel Hempstead, UK). Results of toxicity test were converted to percentages after ANOVA.

\section{RESULTS AND DISCUSSION}

Powders of $X$. aethiopica and D.tripetala fruits at various concentrations on treated rice grains showed significant $(P$ $<0.001)$ mortality of adult $S$. oryzae than the controls. The highest mean number of weevil mortality recorded in $X$. aethiopica treated seeds occurred at $3^{\text {rd }}$ day $(13.17$ at $5 \%$ w/w) (Table 1), and on D. tripetala treated seeds (11.83 at $5 \% \mathrm{w} / \mathrm{w}$ ) (Table 2). The insecticidal activity of both plant powders increased with increased concentrations and days of exposure (Tables 1 and 2). Data from this study also showed that mean number of emerged adult weevils

Table 1. Dose dependent toxicity of Xylopia aethiopica powder on Sitophilus oryzae adult mortality at 24,48 , and $72 \mathrm{~h}$ post treatment under laboratory conditions.

\begin{tabular}{lccc}
\hline & \multicolumn{3}{c}{ Mean $( \pm \mathrm{SE})$ mortality of $S$. oryzae } \\
\cline { 2 - 4 } Treatments $(\%)$ & $24 \mathrm{~h}$ & $48 \mathrm{~h}$ & $72 \mathrm{~h}$ \\
\hline 0 & $0.00 \pm 0.00 \mathrm{e}$ & $1.00 \pm 0.22 \mathrm{e}$ & $1.50 \pm 0.22 \mathrm{f}$ \\
1 & $2.83 \pm 0.31 \mathrm{~d}$ & $3.00 \pm 0.37 \mathrm{~d}$ & $2.33 \pm 0.21 \mathrm{e}$ \\
2 & $8.17 \pm 0.31 \mathrm{c}$ & $8.67 \pm 0.21 \mathrm{c}$ & $8.83 \pm 0.54 \mathrm{~d}$ \\
3 & $9.33 \pm 0.21 \mathrm{~b}$ & $10.17 \pm 0.31 \mathrm{~b}$ & $10.82 \pm 0.31 \mathrm{c}$ \\
4 & $9.83 \pm 0.31 \mathrm{~b}$ & $11.17 \pm 0.40 \mathrm{a}$ & $11.83 \pm 0.31 \mathrm{~b}$ \\
5 & $11.50 \pm 0.43 \mathrm{a}$ & $12.00 \pm 0.52 \mathrm{a}$ & $13.17 \pm 0.48 \mathrm{a}$ \\
$P$ & 0.001 & 0.001 & 0.001 \\
LSD $(0.05)$ & 0.74 & 0.85 & 0.88 \\
\hline
\end{tabular}

Means in the same column followed by the same letter are not significantly different according to Tukey's test $(P>0.05)$.

SE: Standard error of the mean.

Table 2. Dose dependent toxicity of Dennettia tripetala powder on Sitophilus oryzae adult mortality at 24,48 , and $72 \mathrm{~h}$ post treatment under laboratory conditions.

\begin{tabular}{lccc}
\hline & \multicolumn{3}{c}{ Mean $( \pm$ SE) mortality of S. oryzae } \\
\cline { 2 - 4 } Treatments $(\%)$ & $24 \mathrm{~h}$ & $48 \mathrm{~h}$ & $72 \mathrm{~h}$ \\
\hline 0 & $0.50 \pm 0.22 \mathrm{e}$ & $0.83 \pm 0.31 \mathrm{~d}$ & $1.17 \pm 0.31 \mathrm{e}$ \\
1 & $2.00 \pm 0.26 \mathrm{~d}$ & $2.67 \pm 0.33 \mathrm{c}$ & $3.00 \pm 0.52 \mathrm{~d}$ \\
2 & $6.83 \pm 0.48 \mathrm{c}$ & $7.33 \pm 0.56 \mathrm{~b}$ & $7.67 \pm 0.49 \mathrm{c}$ \\
3 & $8.00 \pm 0.26 \mathrm{~b}$ & $9.33 \pm 0.21 \mathrm{a}$ & $9.83 \pm 0.40 \mathrm{~b}$ \\
4 & $8.67 \pm 0.21 \mathrm{~b}$ & $10.33 \pm 0.67 \mathrm{a}$ & $11.17 \pm 0.48 \mathrm{a}$ \\
5 & $10.17 \pm 0.40 \mathrm{a}$ & $10.33 \pm 0.79 \mathrm{a}$ & $11.83 \pm 0.79 \mathrm{a}$ \\
$P$ & 0.001 & 0.001 & 0.001 \\
LSD $(0.05)$ & 0.81 & 1.25 & 1.24 \\
\hline
\end{tabular}

Means in the same column followed by the same letter are not significantly different according to Tukey's test $(P>0.05)$.

SE: Standard error of the mean. in control treatments were significantly $(\mathrm{P}<0.001)$ higher than $F_{1}$ progeny in treated seeds (Table 3 ). The highest mean number of $\mathrm{F}_{1}$ progeny produced in $X$. aethiopica treated seeds was observed in the control (140.50), and the least in 5\% powder treated seeds (31.83). Similarly, with $D$. tripetala treatment, $5 \%$ test had the least mean number of emerged adults (41.17) and the control the highest mean number of 149.67 weevils.

Results from the toxicity of EO showed that S. oryzae was slightly susceptible to both plant oils at a minimum concentration of $0.5 \mathrm{mg} \mathrm{cm}^{-2}$ but highly susceptible at $1 \mathrm{mg} \mathrm{cm}^{-2}$ concentration resulting to 84.17 and $83.33 \%$ mortality for $X$. aethiopica and D. tripetala treatments respectively (Table 4). Complete control (100\% mortality) of the weevil was achieved with $2 \mathrm{mg} \mathrm{cm}^{-2}$ dose treatment of both plants EO after just $24 \mathrm{~h}$ exposure. However, no mortality was obtained in the untreated control. Results of the repellence behavioral tests of EO against $S$. oryzae are shown in Figure 1. Both male (Figure 1a) and female (Figure 1b) weevils showed significant $(P<0.001)$ avoidance behavior to $X$. aethiopica and D. tripetala treated olfactometer arms which contained $10 \mu \mathrm{L}$ EO solution compared to the controls with $10 \mu \mathrm{L}$ solvent (hexane).

Plant natural products that constitute effective safer alternatives to synthetic insecticides without producing adverse effects on the ecosystem have been tested in the management of stored-product pests (Isman, 2006; Ukeh et al., 2009; Mao and Henderson, 2010). In this study, we evaluated the insecticidal and repellent properties of $X$. aethiopica and D. tripetala powders and EO against $S$.

Table 3. Efficacy of Xylopia aethiopica or Dennettia tripetala powders on Sitophilus oryzae progeny emergence at 3-mo post treatment.

\begin{tabular}{lcc}
\hline & \multicolumn{2}{c}{$\mathrm{F}_{1}$ progeny emergence $(\mathrm{mean} \pm \mathrm{SE})$} \\
\cline { 2 - 3 } Doses $(\% \mathrm{w} / \mathrm{w})$ & X. aethiopica & D. tripetala \\
\hline 0 & $140.50 \pm 8.31 \mathrm{a}$ & $149.67 \pm 11.40 \mathrm{a}$ \\
1 & $118.30 \pm 3.94 \mathrm{~b}$ & $125.17 \pm 3.68 \mathrm{~b}$ \\
2 & $68.83 \pm 1.64 \mathrm{c}$ & $75.17 \pm 2.98 \mathrm{c}$ \\
3 & $51.00 \pm 1.53 \mathrm{~d}$ & $56.50 \pm 2.39 \mathrm{~d}$ \\
4 & $40.17 \pm 1.05 \mathrm{e}$ & $48.00 \pm 2.09 \mathrm{de}$ \\
5 & $31.83 \pm 1.89 \mathrm{e}$ & $41.17 \pm 2.54 \mathrm{e}$ \\
$P$ & 0.001 & 0.001 \\
LSD $(0.05)$ & 9.48 & 12.23 \\
\hline
\end{tabular}

Means in the same column followed by the same letter are not significantly different according to Tukey's test $(P>0.05)$.

SE: Standard error of the mean.

Table 4. Efficacy of Xylopia aethiopica or Dennettia tripetala essential oils on the mortality of Sitophilus oryzae adults at $24 \mathrm{~h}$ exposure under laboratory conditions.

\begin{tabular}{lcc}
\hline & \multicolumn{2}{c}{ Mean mortality $(\%) \pm \mathrm{SE}$} \\
\cline { 2 - 3 } Essential oils $\left(\mathrm{mg} \mathrm{cm}^{-2}\right)$ & X.aethiopica & D. tripetala \\
\hline Control & $0.0 \pm 0.00 \mathrm{~d}$ & $0.0 \pm 0.00 \mathrm{~d}$ \\
0.5 & $21.67 \pm 1.67 \mathrm{c}$ & $14.17 \pm 2.01 \mathrm{c}$ \\
1 & $84.17 \pm 2.71 \mathrm{~b}$ & $83.33 \pm 1.67 \mathrm{~b}$ \\
1.5 & $98.33 \pm 1.05 \mathrm{a}$ & $97.50 \pm 1.12 \mathrm{a}$ \\
2 & $100.00 \pm 0.00 \mathrm{a}$ & $100.00 \pm 0.00 \mathrm{a}$ \\
$P$ & 0.001 & 0.001 \\
LSD $(0.05)$ & 3.59 & 3.03 \\
\hline
\end{tabular}

Means in the same column followed by the same letter are not significantly different according to Tukey's test $(P>0.05)$.

SE: Standard error of the mean. 

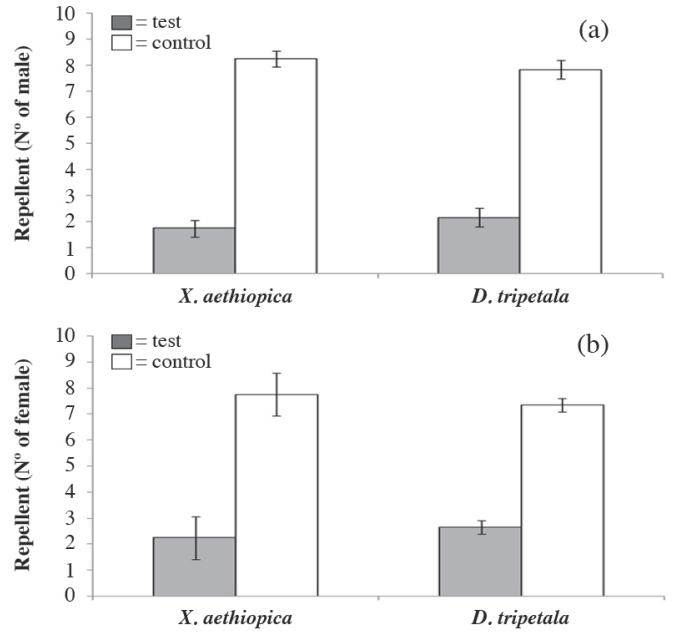

Figure 1. Mean ( \pm SE) repellent effect of Xylopia aethiopica or Dennettia tripetala essential oils against male (a) and female (b) Sitophilus oryzae adults in a Y-Tube olfactometer $(n=12)$

oryzae, under laboratory conditions. Results showed that powders of both herbal plants are toxic to the rice weevil by inhibiting adult survival and suppressing $F_{1}$ progeny emergence. Toxicity tests of the EO also showed that the oils were most effective with $100 \%$ of the insects killed at the highest doses of $2 \mathrm{mg} \mathrm{cm}^{-2}$ at $24 \mathrm{~h}$. Y-tube repellence bioassays using male and female $S$. oryzae unequivocally produced positive results as both sexes preferred the control to the test olfactometer arm. The mode of action of both plant powders against $S$. oryzae was not studied, but it could be the pungent odors prevented the weevil from normal feeding and oviposition, or higher doses of the powders may have blocked the insect spiracles resulting to suffocation and death (Oparaeke and Kuhiep, 2006). These results are in agreement with the reports of Lajide et al. (1995) that $1 \%$ crude extract of X. aethiopica fruit oil exhibited strong antifeedant activity against workers of the subterranean termite, Reticulitermes speratus. The repellent activity of $X$. aethiopica fruit oil against Aedes aegypti mosquito, the carrier of deadly diseases such as yellow fever, dengue fever, filariasis, and encephalitis has also been demonstrated (Adewoyin et al., 2006). On D. tripetala, Egwunyenga et al. (1998) reported the repellent activity of the seed powder and solvent extracts against larvae and adults of the leather beetle, Dermestes maculatus (F.) Inyang and Emosairue (2005) also reported that aqueous extracts of $D$. tripetala seed elicited antifeedant and repellent activity against the banana weevil, Cosmopolites sordidus (Germar).

Studies on the insecticidal, antifeedant, and repellent effects of other plant extracts against $S$. oryzae have been documented from other published papers. For example, Park et al. (2003) reported that Acorus gramineus (Araceae) rhizome-derived extracts elicited 70 and $90 \%$ mortality against $S$. oryzae adults at 0.064 and $0.255 \mathrm{mg}$ $\mathrm{cm}^{-2}$ at $4 \mathrm{~d}$ after treatment. Insecticidal and fumigant activities of EO obtained from dry ground leaves of Artemisia scoparia (Asteraceae) against S. oryzae, $C$. maculatus, and Tribolium castaneum (Herbst) have been demonstrated (Negahban et al., 2006). Similarly, the fumigant and repellent effects of Ocimum gratissimum (Labiatae) oil and its constituents against S. oryzae, $T$. castaneum, Oryzaephilus surinamensis (L.), and Rhyzopertha dominica (F.) have also been reported. The efficacy of $O$. gratissimum oil was influenced by concentration and duration of exposure after treatment (Ogendo et al., 2008). Omar et al. (2007) showed that extracts from the bark of Lansium domesticum (Meliaceae) had caused significant feeding inhibition of $S$. oryzae under laboratory conditions. In this study, the repellence of $X$. aethiopica or D. tripetala EO against $S$. oryzae is also in agreement with Yoon et al. (2007), who previously reported the repellent efficacy of Carum carvii (Umbelliferae) and Citrus paradise (Rutaceae) oils against $S$. oryzae in a T-tube olfactometer. Essential oil from the seed of $C$. carvii also exhibited toxic fumigant activity against $S$. oryzae at a dose of $1 \mu \mathrm{L} \mathrm{mL}^{-1}$ of volume on $2 \mathrm{~cm}$ filter paper disc (López et al., 2008).

Plant products including EO and their constituents are a mixture of biologically active substances or secondary metabolites of defensive nature that have been broadly studied for pest management purposes (Isman, 2006; Pavela, 2011). Essential oils are a very complex mixture of terpenes, sesquiterpenes, their oxygenated derivatives and other aromatic compounds. The chemical composition of EO may vary among plants, species, chemotype, climate, soil conditions, geographical location and the method of extraction (Langenheim, 1994; Wang and Lincoln, 2004; Nerio et al., 2010; Zapata and Smagghe, 2010). The mechanism of action of EO and their chemical components could affect the biochemical processes and disrupt the endocrine balance of insects (Reynolds, 1987; Rattan, 2010). The action of EO may also produce neurotoxicity in insects giving symptoms similar to those produced by organophosphates and carbamates insecticides (Isman, 2000; Ukeh and Umoetok, 2011), which are often characterized by hyperactivity, hyper-excitation leading to rapid knock down and immobilization (Enan, 2001; Rattan, 2010). Several EO and their components have been shown as reversible inhibitors of acetylcholinesterase (AChE) (Ryan and Byrne, 1988). Acetylcholinesterase hydrolyses acetylcholine (Ach), to choline and acetate thereby regulating nerve impulse transmission across cholinergic synapses (Siegfried and Scott, 1990; López and PascualVillalobos, 2010). Octopamine (OA), a multifunctional biogenic amine which plays key roles as neurotransmitter, neuromodulator, and neurohormone in invertebrates is another target of EO. The acute and sublethal behavioral effects of EO act by blocking octopamine receptors (Enan, 2005). The chemical constituents of X. aethiopica have been identified as diterpenes (Ngouela et al., 1998), 
diterpenes, phenolic amides and lignanamides (Lajide et al., 1995), monoterpenes, sesquiterpenes, oxygenated terpenes, and aromatic hydrocarbons (Boyom et al., 2003). Methanolic extract of the roots of $D$. tripetala isolated by chromatographic techniques resulted to the chromone alkaloid dennettine, three phenanthrene alkaloids identified as uvariopsine, stephenanthrine, and argentinine and a simple phenolic compound vanillin (López-Martin et al., 2002). Data from this study clearly indicate that $X$. aethiopica and D. tripetala powders and EO elicited direct adult mortality, antifeedant behavior, reduced $\mathrm{F}_{1}$ progeny emergence, and repellence of $S$. oryzae under laboratory conditions.

\section{CONCLUSIONS}

Based on the results obtained in the current study, it may be concluded that $X$. aethiopica and D. tripetala plant materials have a broad spectrum of activity against $S$. oryzae, and the extracts could have potentials as bioinsecticides in stored-product protection. However, since plant products volatilize quickly in the environment and do not persist for longer duration unlike synthetic pesticides, there could be a need for re-application to obtain the desired results. The efficacy of plant-based pesticides could also be enhanced when dissolved or mixed with a slow-release fixative material or carrier such as starch or liquid paraffin, and incorporated as an integral part of integrated pest management system especially at a small-scale farmer level.

Efecto insecticida de extractos de fruta de Xylopia aethiopica y Dennettia tripetala (Annonaceae) contra Sitophilus oryzae (Coleoptera: Curculionidae). La actividad insecticida y repelente de los extractos frutales de Xylopia aethiopica (Dunal) A. Rich. y Dennettia tripetala (Baker f.) G.E. Schatz pertenecientes a la familia Annonaceae fueron evaluados contra Sitophilus oryzae (L.), plaga primaria de importancia económica en poscosecha de arroz y otros cereales. Granos de arroz $(100 \mathrm{~g})$ infestados tratados con polvos de ambas plantas al $1,2,3,4, y 5 \%(\mathrm{p} / \mathrm{p})$ fueron evaluados para la toxicidad contra $S$. oryzae cada $24 \mathrm{~h}$ por $3 \mathrm{~d}$ y durante la emergencia de la progenie $F_{1}$. Los aceites esenciales de ambas plantas también fueron aplicados en papel filtro a 0,$5 ; 1 ; 1,5$ y 2 $\mathrm{mg} \mathrm{cm}{ }^{-2}$ en cajas de Petri para bioensayos de toxicidad con exposición de $24 \mathrm{~h}$. Bioensayos de repelencia con 10 $\mu \mathrm{L}$ de solución de los aceites esenciales impregnados en papel filtro fueron realizados en un olfatómetro de flujo de aire Y-Tube. Los resultados indican que los polvos de ambas plantas causan una mortalidad significativa de estos insectos $(P<0,001)$ y una reducción en la emergencia de la progenie $F_{1}$ con relación al control. Los aceites esenciales también mostraron un efecto adulticida significativo $(\mathrm{P}<$ $0,001)$ después de $24 \mathrm{~h}$ con la dosis más alta $\left(2 \mathrm{mg} \mathrm{cm}^{-2}\right)$, produciendo un $100 \%$ de mortalidad. De igual manera, tanto hembras como machos de $S$. oryzae evitan el tratamiento en una proporción significativamente mayor al control en los ensayos de repelencia en el olfatómetro Y-Tube. Estos resultados sugieren que los extractos naturales de $X$. aethiopica and $D$. tripetala tienen un uso potencial en el manejo integrado de plagas de productos almacenados contra S. oryzae.

Palabras clave: aceites esenciales, polvos, repelencia, toxicidad, olfatómetro Y-Tube.

\section{LITERATURE CITED}

Adewoyin, F.B., A.B. Odaibo, and C.O. Adewunmi. 2006. Mosquito repellent activity of Piper guineense and Xylopia aethiopica fruits oils on Aedes aegypti. African Journal of Traditional Complementary and Alternative Medicines 3(2):79-83.

Bekele, J., and A. Hassanali. 2001. Blend effects in the toxicity of the essential oil constituents of Ocimum kilimandscharicum and Ocimum kenyense (Labiateae) on two post-harvest insect pests. Phytochemistry 57:385-391.

Boyom, F.F., V. Ngouana, P.H.A. Zollo, C. Menut, J.M. Bessiere, J. Gut, and P.J. Rosenthal. 2003. Composition and anti-plasmodial activities of essential oils from some Cameroonian medicinal plants. Phytochemistry 64:1269-1275

Daglish, G.J. 2004. Effect of exposure period on degree of dominance of phosphine resistance in adults of Rhyzopertha dominica (Coleopetera: Bostrychidae) and Sitophilus oryzae (Coleoptera: Curculionidae). Pest Management Science 60:822-826.

Dal Bello, G., S. Padin, C. López Lastra, and M. Fabrizio. 2001. Laboratory evaluation of chemical-biological control of the rice weevil (Sitophilus oryzae L.) in stored grains. Journal of Stored Products Research 37:77-84.

Egwunyenga, O.A., E.B. Alo, and P.G. Nmorsi. 1998. Laboratory evaluation of the repellency of Dennettia tripetala Baker (Annonaceae) to Dermestes maculatus (F.) (Coleoptera: Dermestidae). Journal of Stored Products Research 34:195-199.

Ejechi, B.O., and D.E. Akpomedaye. 2005. Activity of essential oil and phenolic acid extracts of pepper fruit (Dennetia tripetala $\mathrm{G}$. Baker) against some food-borne microorganisms. African Journal of Biotechnology 4:258-261.

Enan,E.E. 2001. Insecticidal activity of essential oils: Octopaminergic sites of action. Comparative Biochemistry and Physiology-Part C: Toxicology and Pharmacology 130:325-337.

Enan, E.E. 2005. Molecular and pharmacological analysis of an octopamine receptor from American cockroach and fruit fly in response to plant essential oils. Archives of Insect Biochemistry and Physiology 59:161-171.

Inyang, U.E., and S.O. Emosairue. 2005. Laboratory assessment of the repellent and anti-feedant properties of aqueous extracts of 13 plants against the banana weevil Cosmopolites sordidus Germar (Coleoptera: Curculionidae). Tropical and Subtropical Agroecosystems 5:33-44.

Isman, M.B. 2000. Plant essential oils for pest and disease management. Crop Protection 19:603-608.

Isman, M.B. 2006. Botanical insecticides, deterrents, and repellents in modern agriculture and an increasingly regulated World. Annual Review of Entomology 51:45-66.

Lajide, L., P. Escoubas, and J. Mizutani. 1995. Termite antifeedant activity in Xylopia aethiopica. Phytochemistry 40:1105-1112.

Langenheim, J.H. 1994. Higher plant terpenoids: a phytocentric overview of their ecological roles. Journal of Chemical Ecology 20:1223-1280

López, M.D., M.J. Jordán, and M.J. Pascual-Villalobos. 2008. Toxic compounds in essential oils of coriander, caraway and basil active against stored rice pests. Journal of Stored Products Research 44:273-278. 
López, M.D., and M.J. Pascual-Villalobos. 2010. Mode of inhibition of acetylcholinesterase by monoterpenoids and implications for pest control. Industrial Crops and Products 31:284-288.

López-Martin, J., M.A. Edet, H. Boira, M.J. Sanz, and M.A. Blázquez. 2002. Chromone and phenanthrene alkaloids from Dennettia tripetala. Chemical and Pharmaceutical Bulletin 50:1613-1615.

Mao, L., and G. Henderson. 2010. Evaluation of potential use of nootkatone against maize weevil (Sitophilus zeamais Motschulsky) and rice weevil [S. oryzae (L.)] (Coleoptera: Curculionidae). Journal of Stored Products Research 46:129-132.

Negahban, M., S. Moharramipour, and F. Sefidkon. 2006. Chemical composition and insecticidal activity of Artemisia scoparia essential oil against three Coleopteran stored-product insects. Journal of Asia-Pacific Entomology 9:381-388.

Nerio, L.S., J. Olivero-Verbel, and E. Stashenko. 2010. Repellent activity of essential oils: A review. Bioresource Technology 101:372-378.

Ngouela, S., B. Nyassé, E. Tsamo, N-C. Brochier, and C. Morin. 1998. A trachylobane diterpenoid from Xylopia aethiopica. Journal of Natural Products 61:263-266.

Nwachukwu, E.O., and J.O. Osuji. 2008. Evaluation of plant extracts for antifungal activity against Sclerotium rolfsii causing cocoyam cormel rot in storage. Research Journal of Agricultural and Biological Sciences 4:784-787.

Ogendo, J.O., M. Kostyukovsky, U. Ravid, J.C. Matasyoh, A.L. Deng, E.O. Omolo, et al. 2008. Bioactivity of Ocimum gratissimum L. oil and two of its constituents against five insect pests attacking stored food products. Journal of Stored Products Research 44:328-334.

Okigbo, R.N., C.S. Mbajiuka, and C.O. Njoku. 2005. Antimicrobial potentials of (UDA) Xylopia aethiopica and Ocimum gratissimum L. on some pathogens of man. International Journal of Molecular Medicine and Advanced Sciences 1:392-397.

Omar, S., M. Marcotte, P. Field, P.E. Sanchez, L. Poveda, R. Mata, et al. 2007. Antifeedant activities of terpenoids isolated from tropical Rutales. Journal of Stored Products Research 43:92-96.

Oparaeke, A.M., and G.C. Kuhiep. 2006. Toxicity of powders from indigenous plants against Sitophilus zeamais Motsch. on stored grains. Journal of Entomology 3:216-221.

Park, C., S-I. Kim, and Y-J. Ahn. 2003. Insecticidal activity of asarones identified in Acorus gramineus rhizome against three coleopteran stored-product insects. Journal of Stored Products Research 39:333-342.

Pavela, R. 2011. Insecticidal and repellent activity of selected essential oils against the pollen beetle, Meligethes aeneus (Fabricius) adults. Industrial Crops and Products 34:888-892.
Phillips, T.W., and J.E. Throne. 2010. Biorational approaches to managing stored-product insects. Annual Review of Entomology 55:375-397.

Rajendran, S., and N. Muralidharan. 2001. Performance of phosphine in fumigation of bagged paddy rice in indoor and outdoor stores Journal of Stored Products Research 37:351-358.

Rattan, R.S. 2010. Mechanism of action of insecticidal secondary metabolites of plant origin. Crop Protection 29:913-920.

Rees, D. 2004. Insects of stored products. CSIRO Publishing, Collingwood, Australia.

Reynolds, S.E. 1987. The cuticle, growth and moulting in insects: the essential background to the action of acylurea insecticides Pesticide Science 20:131-146.

Ryan, M.F., and O. Byrne. 1988. Plant-insect coevolution and inhibition of acetylcholinesterase. Journal of Chemical Ecology 14:1965-1975.

Siegfried, B.D., and S.C. Scott. 1990. Biochemical characterization of hydrolytic and oxidative enzyme in insecticide resistant and susceptible strain of the German cockroach (Dictyoptera: Blattellidae). Journal of Economic Entomology 85:1092-1098.

Sousa, A., L. Faroni, M. Pimentel, and R. Guedes. 2009. Developmental and population growth rates of phosphine-resistant and susceptible populations of stored-product insect pests. Journal of Stored Products Research 45:241-246.

Ukeh, D.A., M.A. Birkett, J.A. Pickett, A.S. Bowman, and A.J Luntz. 2009. Repellent activity of alligator pepper, Aframomum melegueta, and ginger, Zingiber officinale against the maize weevil, Sitophilus zeamais. Phytochemistry 70:751-758.

Ukeh, D.A., and S.B.A. Umoetok. 2011. Repellent effects of five monoterpenoid odours against Tribolium castaneum (Herbst) and Rhyzopertha dominica (F.) in Calabar, Nigeria. Crop Protection 30:1351-1355.

Wang, M., and D. Lincoln. 2004. Effect of light intensity and artificial wounding on monoterpenes production in Myrica cerifera from two different ecological habitats. Canadian Journal of Botany 82:1501-1508.

Yoon, C., S-H. Kang, S-A. Jang, Y-J. Kim, and G-H. Kim. 2007. Repellent efficacy of caraway and grapefruit oils for Sitophilus oryzae (Coleoptera: Curculionidae). Journal of Asia-Pacific Entomology 10:263-267.

Zapata, N., and G. Smagghe. 2010. Repellency and toxicity of essential oils from the leaves and bark of Laurelia sempervirens and Drimys winteri against Tribolium castaneum. Industrial Crops and Products 32:405-410. 